\title{
IDENTIFIKASI IKAN DI PELABUHAN PERIKANAN TANJUNG LUAR, PULAU LOMBOK, PROVINSI NUSA TENGGARA BARAT
}

\section{IDENTIFICATION OF FISH IN TANJUNG LUAR FISHING PORT, LOMBOK ISLAND, NUSA TENGGARA BARAT PROVINCE}

\author{
Slamet Mardiyanto Rahayu*1, Syuhriatin², Desy Iftiana ${ }^{3}$ \\ 1,2,3Universitas Islam Al-Azhar, Mataram, Nusa Tenggara Barat \\ *email: slamet.mardiyantorahayu84@gmail.com
}

\begin{abstract}
ABSTRAK
Sumberdaya ikan adalah jenis ikan termasuk biota perairan laut lainnya yang merupakan sumber kekayaan alam yang memiliki daya pulih kembali secara alami, sehingga pemanfaatannya dapat dilakukan secara berkelanjutan. Pelabuhan perikanan merupakan tempat pendaratan hasil tangkapan dan awal pemasarannya. jenis ikan hasil tangkapan nelayan yang didaratkan di Pelabuhan Perikanan Pantai Tanjung Luar, Kabupaten Lombok Timur. Penelitian dilakukan dengan metode survey dan identifikasi. Berdasarkan penelitian diperoleh sebanyak 34 jenis ikan hasil tangkapan nelayan di Pelabuhan Perikanan Tanjung Luar, Pulau Lombok, yaitu: Naso brevisrostris, Chanos chanos, Parastromateus niger, Thallasoma purpureum, Siganus canaliculatus, Plectorhinchus polytaenia, Diodon holocanthus, Upeneus vittatus, Caesio cuning, Dermogenys sp, Epinephelus areolatus, Rastrelliger sp, Pomadasys argenteus, Lepturacanthus savala, Decapterus macrosoma, Sillago sihama, Eusphyra blochii, Carcharhinus brevipinna, Carcharhinus albimarginatus, Carcharhinus limbatus, Carcharhinus obscurus, Galeocerdo cuvier, Prionace glauca, Taeniura lymma, Priancanthus hamrur, Scolopsis sp, Scombermorus guttatus, Euthynnus affinis, Nemipterus japonicas, Sardinella sp, Lutjanus bitaeniatus, Secutor interruptus, Sphyraena jello, dan Caranx ignobilis.
\end{abstract}

\section{Kata Kunci: Ikan, Pelabuhan Perikanan Tanjung Luar, Pulau Lombok}

\begin{abstract}
Fish resources are types of fish including other marine biota which are natural resources that have the ability to recover naturally, so that their utilization can be carried out sustainably. The fishing port is the landing place for catches and the beginning of its marketing. types of fish caught by fishermen landed at the Port of Tanjung Luar Beach Fisheries, East Lombok Regency. The study was conducted by survey and identification methods. Based on the research, there were 34 types of fish caught by fishermen at the Port of Tanjung Luar Fisheries, Lombok Island, namely: Naso brevisrostris, Chanos chanos, Parastromateus niger, Thallasoma purpureum, Siganus canaliculatus, Plectorhinchus polytaenia, Diodon holocanthus, Upeneus vittatus, Caesio cuning, Dermogenys sp, Epinephelus areolatus, Rastrelliger sp, Pomadasys argenteus, Lepturacanthus savala, Decapterus macrosoma, Sillago sihama, Eusphyra blochii, Carcharhinus brevipinna, Carcharhinus albimarginatus, Carcharhinus limbatus, Carcharhinus obscurus, Galeocerdo cuvier, Prionace glauca, Taeniura lymma, Priancanthus hamrur, Scolopsis sp, Scombermorus guttatus, Euthynnus affinis, Nemipterus japonicas, Sardinella sp, Lutjanus bitaeniatus, Secutor interruptus, Sphyraena jello, and Caranx ignobilis.
\end{abstract}

Keyword: Fish, Tanjung Luar Fishing Port, Lombok Island 
$\underline{\text { Identifikasi Ikan Di Pelabuhan Perikanan Tanjung Luar...............(Slamet Mardiyanto Riyadi) }}$

\section{PENDAHULUAN}

Indonesia merupakan negara kepulauan yang terdiri lebih dari 17.500 pulau, dimana 6000 pulau diantaranya tidak berpenghuni. Indonesia adalah salah satu negara terbesar dalam Coral Triangle, pusat global laut endemik, dan dianggap memiliki fauna terumbu karang terkaya di dunia. Bahkan lebih dari setengah spesies ikan terumbu karang yang terdapat di IndoPasifik terdapat di laut Indonesia. Oleh karena itu, tingkat keragaman ikan yang berinteraksi dengan berbagai perikanan sangat tinggi (White et al., 2013).

Sumberdaya ikan adalah jenis ikan termasuk biota perairan laut lainnya yang merupakan sumber kekayaan alam yang memiliki daya pulih kembali secara alami, sehingga pemanfaatannya dapat dilakukan secara berkelanjutan sepanjang menggunakan cara pemanfaatan dengan kaidah yang benar (Agus \& Laga, 2012). Ikan laut sangat penting untuk dikonsumsi karena merupakan sumber protein yang berguna bagi kesehatan. Ikan juga berfungsi sebagai bahan baku industri pengolahan. Peluang pasar hasil tangkapan dari laut pun masih terbuka lebar, baik untuk memenuhi kebutuhan dalam negeri maupun untuk menembus pasar global yang dapat menambah devisa Negara (Barani, 2004). Sumberdaya ikan yang hidup di wilayah perairan Indonesia dinilai memiliki tingkat keragaman hayati (biodiversity) paling tinggi. Sumberdaya tersebut paling tidak mencakup $37 \%$ dari spesies ikan di dunia. Di wilayah perairan laut Indonesia

terdapat beberapa jenis ikan bernilai ekonomis tinggi antara lain: tuna, cakalang, udang, tongkol, tenggiri, kakap, cumicumi, ikan-ikan karang (kerapu, baronang, udang barong/lobster), ikan hias dan kekerangan termasuk rumput laut (Barani, 2004).
Pelabuhan perikanan merupakan tempat pendaratan hasil tangkapan dan awal pemasarannya. Menurut Direktorat Jenderal Perikanan Republik Indonesia, pelabuhan perikanan adalah pelabuhan yang secara khusus menampung kegiatan masyarakat baik dilihat dari aspek produksi, pengolahan maupun aspek pemasarannya.

Di Indonesia dari 34 Provinsi terdapat 151 pelabuhan perikanan, di mana Provinsi Nusa Tenggara Barat memiliki 6 pelabuhan yang tersebar di masing-masing Kabupaten, salah satunya di Kabupaten Lombok Timur yaitu Pelabuhan Perikanan Tanjung Luar yang terletak di Desa Tanjung Luar, Kecamatan Keruak. Perairan Lombok Timur masih memiliki peluang potensi perikanan yang amat besar untuk dioptimalkan. Pangkalan Pendaratan Ikan (PPI) Tanjung Luar di Provinsi Nusa Tenggara Barat ini berdasarkan Keputusan Menteri Kelautan dan Perikanan Republik Indonesia Nomor 33/KEPMEN-KP/2016 pada tanggal 20 Juli 2016. Tanjung Luar merupakan salah satu desa yang ada di Kecamatan Keruak, Kabupaten Lombok Timur, Provinsi Nusa Tenggara Barat, Indonesia yang jumlah penduduknya sebagian besarbersuku daerah Sasak, Bugis dan Bajau. Desa Tanjung luar memiliki jumlahpenduduk 17.781 orang yang terdiri dari 4117 kepala kelaurga (KK), dan yangberprofesi sebagai nelayan berjumlah 5.278 orang.

Berdasarkan hal tersebut maka perlu diketahui jenis ikan hasil tangkapan nelayan yang didaratkan di Pelabuhan Perikanan Pantai Tanjung Luar, Kabupaten Lombok Timur.

\section{METODOLOGI}

Penelitian dilakukan di Pelabuhan Perikanan Pantai Tanjung Luar, kecamatan Keruak, Kabupaten Lombok Timur, Pulau Lombok, Nusa Tenggara Barat. Pendataan 
jenis ikan hasil tangkapan nelayan dilakukan pada pagi hari antara jam 07.00 - 09.00 WITA saat nelayan baru mendarat dari mencari ikan di laut. Setiap jenis ikan didokumentasikan dan diambil masingmasing 1 ekor dari setiap jenis ikan sebagai sampel untuk didentifikasi lebih lanjut dengan mengacu pada buku Market Fishes of Indonesia (White et al., 2013). Setiap jenis ikan diamati dan dicatat karakteristik morfologinya. Hasil identifikasi kemudian ditabulasi meliputi nama jenis (spesies), nama lokal, dan familinya.

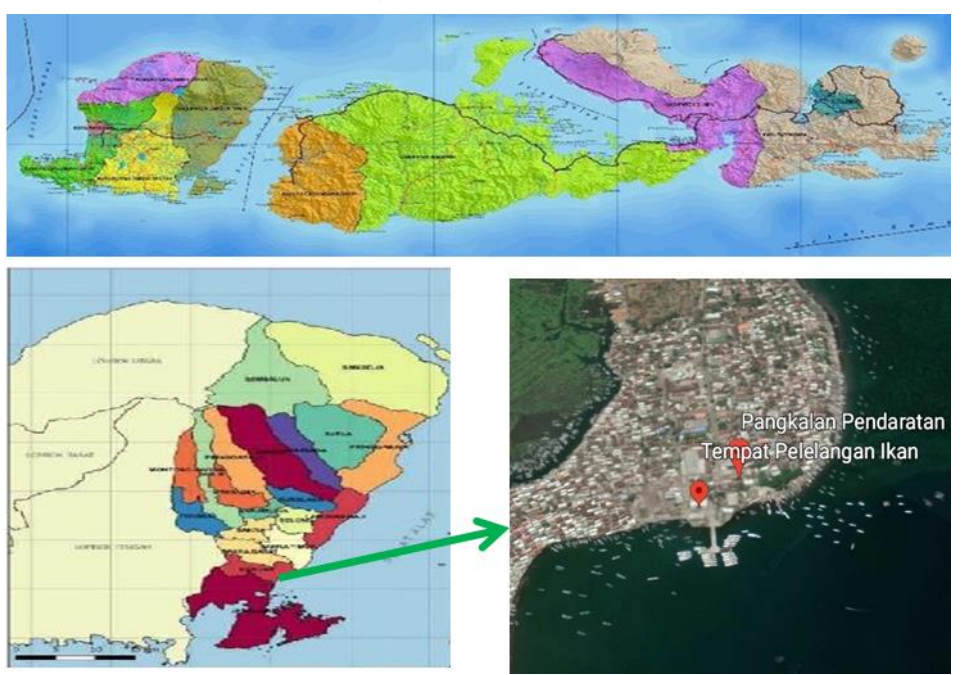

Gambar 1. Lokasi Penelitian di Pelabuhan Perikanan Pantai Tanjung Luar, Pulau Lombok, Nusa Tenggara Barat (846’40’S 116³1'00’E).

\section{HASIL DAN PEMBAHASAN}

Berdasarkan hasil penelitian diperoleh sebanyak 34 jenis ikan hasil tangkapan nelayan yang didaratkan di Pelabuhan Perikanan Pantai Tanjung Luar, Kecamatan Keruak, Kabupaten Lombok Timur.

Tabel 1. Jenis ikan hasil tangkapan nelayan yang didaratkan di Pelabuhan Perikanan Pantai Tanjung Luar, Kabupaten Lombok Timur

\begin{tabular}{llll}
\hline No & Nama Lokal & Nama Spesies & Famili \\
\hline 1 & Empa' Ayam - Ayam & Naso brevisrostris & Acanthuridae \\
\hline 2 & Empa' Bandeng & Chanos chanos & Chanidae \\
\hline 3 & Empa' Bawal & Parastromateus niger & Carangidae \\
\hline 4 & Empa' Bayem/ Lembain & Thallosoma purpureum & Labridae \\
\hline 5 & Empa' Beronang Lada & Siganus canaliculatus & Siganidae \\
\hline 6 & Empa' Bibir Tebal/ Pelabatu & Plectrohinchus polytaenia & Haemulidae \\
\hline 7 & Empa' Buntel Duri & Diodon holocanthus & Diodontidae \\
\hline 8 & Empa' Kuniran & Upeneus vittatus & Mullidae \\
\hline 9 & Empa' Ekor Kuning & Caesio cuning & Caesionidae \\
\hline 10 & Empa' Julung - Julung & Dermogenys sp & Hamiramphidae \\
\hline 11 & Empa' Kerapu Tutul & Epinephelus areolatus & Serranidae \\
\hline 12 & Empa' Kembung/ Layah & Rastrellinger kanagurta & Scombridae \\
\hline 13 & Empa' Krot - Krot & Pomadasys argenteus & Haemulidae \\
\hline 14 & Empa' Layur & Lepturacanthus savala & Trichiuridae
\end{tabular}




\begin{tabular}{llll}
\hline 15 & Empa' Layang & Decapterus macrosoma & Carangidae \\
\hline 16 & Empa' Kacangan/ Bojor & Sillago sihama & Sillaginidae \\
\hline 17 & Empa' Hiu Martil & Eusphyra blochii & Sphyrnidae \\
\hline 18 & Empa' Hiu Sonteng & Carcharhinus albimarginatus & Carcharhinidae \\
\hline 19 & Empa' Hiu Lonjor & Carcharhinus amblyrhynchos & Carcharhinidae \\
\hline 20 & Empa' Hiu Kejen & Carcharhinus limbatus & Carcharhinidae \\
\hline 21 & Empa' Hiu Merak Bulu & Carcharhinus obscurus & Carcharhinidae \\
\hline 22 & Empa' Hiu Macan & Galeocerdo cuvier & Carcharhinidae \\
\hline 23 & Empa' Hiu Karet & Prionace glauca & Carcharhinidae \\
\hline 25 & Empa' Pari Hias / Tutul & Taeniura lymma & Dasyatidae \\
\hline 26 & Empa' Mate Beleq & Priancanthus hamrur & Priacanthidae \\
\hline 27 & Empa' Biji Nangka & Scolopsis sp & Nemipteridae \\
\hline 28 & Empa' Tongkol & Scomberomorus guttatus & Scombridae \\
\hline 29 & Empa' Kurisi Beaq & Euthynnus affinis & Scombridae \\
\hline 30 & Empa' Sembulak & Nemipterus japonicas & Nemipteridae \\
\hline 31 & Empa' Kakap Beaq & Sardinella sp & Clupeidae \\
\hline 32 & Empa' Semar & L. bitaeniatus & Lutjanidae \\
\hline 33 & Empa' Ucul/ Senuk & Secutor interruptus & Leiognathidae \\
\hline 34 & Empa' Kuwe & Sphyraena jello & Sphyraenidae \\
\hline
\end{tabular}

Empa' Ayam-Ayam (Naso brevisrostris) dapat tumbuh hingga $60 \mathrm{~cm}$. Hidup di daerah terumbu karang dengan kedalaman 122 meter di sepanjang rataan terumbu sampai tubiran, dan juga dapat di temukan disepanjang pantai bebatuan. Ikan ini ketika masih kecil hidup dengan memakan alga dan saat dewasa hidup dengan memakan zooplankton.

Empa' Bandeng (Chanos chanos) yang dikonsumsi biasanya berukuran 20 $30 \mathrm{~cm}$. Saat kecil ikan ini hidup di muara sungai, pantai dan dermaga, bahkan masuk jauh ke sungai untuk mencari makan. Ikan yang besar berada di laut lepas dengan kedalaman 1 - 30 meter.

Empa' Bawal (Parastromateus niger) yang dikonsumsi berukuran $20-30$ $\mathrm{cm}$. Hidup di terumbu karang, muara atau air payau sampai laut lepas dengan kedalaman 15 - 105 meter. Ikan ini hidup dengan memakan zoopankton.

Empa' Bayem/ Lembain (Thallasoma purpureum) dapat tumbuh hingga $46 \mathrm{~cm}$ dengan berat $1.2 \mathrm{~kg}$. Hidup di sekitar terumbu karang dengan kedalaman 1 - 10 meter. Ikan ini hidup dengan memakan berbagai hewan yng hidup di pasir putih dan sekitar karang.

Empa' Beronang Lada (Siganus canaliculatus) dapat tumbuh hingga $30 \mathrm{~cm}$. Hidup di daerah terumbu karang, air payau, muara sungai, dan laut dengan kedalaman 3 - 50 meter. Ikan ini hidup dengan memakan alga, lumut, dan zooplankton.

Empa' Bibir Tebal/ Pelabatu (Plectorhinchus polytaenia) dapat tumbuh hingga $50 \mathrm{~cm}$, hidup di sekitar terumbu karang sampai kedalaman 30 meter, merupakan ikan nokturnal yang hidup disekitar gua karang. Ikan muda hidup dalam kelompok kecil, sedangkan setelah dewasa hidup berpasangan atau soliter.

Empa' Buntel Duri (Diodon holocanthus) dapat tumbuh mencapai $50 \mathrm{~cm}$, dengan tubuh bulat seperti bola, terdapat banyak duri di sepanjang tubuhnya. Hidup di sekitar terumbu karang pada kedalaman 2 - 200 meter. 

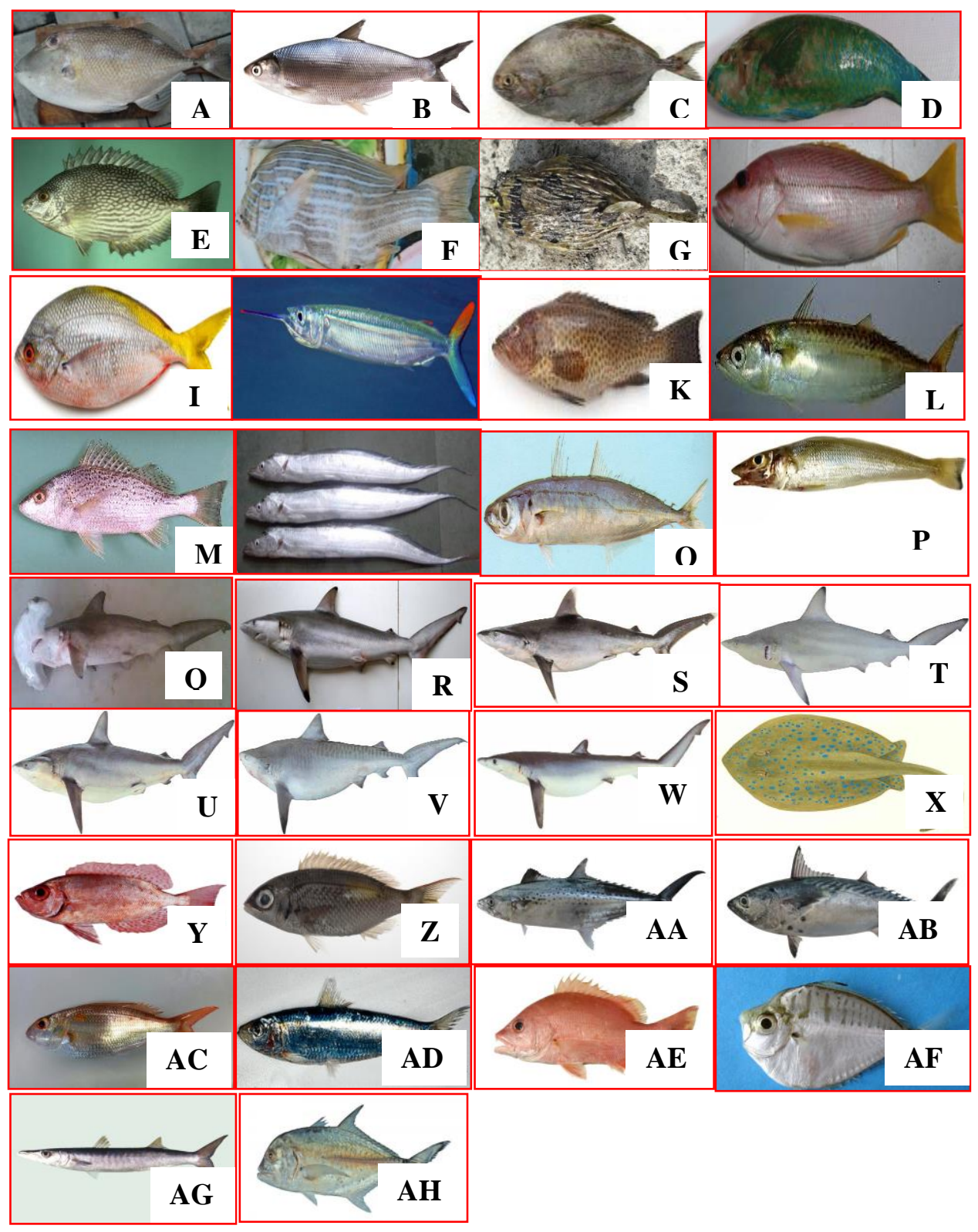

Gambar 2. Ikan hasil tangkapan nelayan di Pelabuhan Perikanan Tanjung Luar, Pulau Lombok A: Naso brevisrostris, B: Chanos chanos, C: Parastromateus niger, D: Thallasoma purpureum, E: Siganus canaliculatus, F: Plectorhinchus polytaenia, G: Diodon holocanthus, H: Upeneus vittatus, I: Caesio cuning, J: Dermogenys sp, $\mathrm{K}$ : Epinephelus areolatus, L: Rastrelliger sp, M: Pomadasys argenteus, N: Lepturacanthus savala, O: Decapterus macrosoma, P: Sillago sihama, Q: Eusphyra blochii, R: Carcharhinus brevipinna, S: Carcharhinus albimarginatus, T: Carcharhinus limbatus, U: Carcharhinus obscurus, V: Galeocerdo cuvier, W: Prionace glauca, X: Taeniura lymma, Y: Priancanthus hamrur, Z: Scolopsis sp, AA: Scombermorus guttatus, AB: Euthynnus affinis, AC: Nemipterus japonicas, AD: Sardinella sp, AE: Lutjanus bitaeniatus, AF: Secutor interruptus, AG: Sphyraena jello, AH: Caranx ignobilis 
Empa' Kuniran (Upeneus vittatus) dapat tumbuh hingga mencapai $25 \mathrm{~cm}$. Hidup di pantai berpasir dengan kedalaman 100 meter. Ikan ini hidup bergerombol sambil mengaduk-aduk pasir untuk mencari hewan - hewan kecil menggunakan mulutnya.

Empa' Ekor Kuning (Caesio cuning) dapat tumbuh hingga mencapai $35 \mathrm{~cm}$. Hidup di sekitar terumbu karang dan pantai, tidak suka berada di muara. Hidup bergerombol di permukaan dan di sekitar karang sampai kedalaman 100 meter. Ikan ini hidup dengan memakan berbagai hewan seperti udang, larva ikan dan moluska.

Empa' Julung - Julung/ Oras/ Peje (Dermogenys sp) dapat tumbuh hingga mencapai panjang $30 \mathrm{~cm}$, dengan ciri tubuh gepeng dan rahang bawah panjang. Ikan ini tersebar luas dan terdapat di sungai sungai dekat pantai di daerah tropis.

Empa' Kerapu Tutul (Epinephelus areolatus) dapat tumbuh hingga $47 \mathrm{~cm}$ dengan berat $1,4 \mathrm{~kg}$. Ikan ini hidup di sekitar rumput laut di bersubstrat pasir, dan biasanya hanya terdapat di laut dalam. Habitat ikan ini mulai dari sungai, aip payau sampai laut lepas.

\section{Empa' Kembung Bui-Bui} (Rastrelliger sp) merupakan ikan diurnal yang banyak terdapat pada lapisan pelagis. Zooplankton merupakan salah satu makanan utama ikan kembung, sehingga penyebaran ikan kembung diduga mengikuti pergerakan horizontal plankton tersebut. Ikan kembung hidup berkelompok dalam jumlah yang besar pada perairan pantai dengan kedalaman antara $10-50 \mathrm{~m}$.

Empa' Krot - Krot (Pomadasys argenteus) hidup di sekitar pelabuhan, pantai, dermaga, dan muara sungai. Jenis ini hidup di tempat yang dangkal, suka berada di substrat lumpur, pasir dan juga di sekitar terumbu karang. Dapat tumbuh hingga 50 $\mathrm{cm}$, tetapi biasanya yang dijual berukuran 20
- $30 \mathrm{~cm}$. Ikan ini hidup dengan memakan molusca, termasuk yang bercangkang.

Empa' Layur (Lepturacanthus savala) merupakan ikan nocturnal yang dapat tumbuh hingga mencapai 1 meter. Hidup di air payau dan laut lepas sampai kedalaman 100 meter.

Empa' Layang (Decapterus macrosoma) dapat tumbuh hingga $35 \mathrm{~cm}$, terdapat di sekitar pantai. Hidup secara berkelompok dengan memakan plankton.

Empa' Kacangan / Ikan Bojor (Sillago sihama) merupakan ikan yang dapat tumbuh sampai $45 \mathrm{~cm}$. Ikan ini biasanya hidup berkelompok dan memakan kepiting, moluska, dan beberapa ikan kecil.

Empa' Hiu Martil (Eusphyra blochii) lebih suka berada di laut yang arusnya tidak terlalu kencang. Kepala ikan ini digunakan untuk bermanuver dan sebagai indera untuk mendeteksi mangsa. Ikan hiu ini memakan ikan, udang dan molusca.

Empa' Hiu Lonjor (Carcharhinus brevipinna) dapat tumbuh hingga mencapai ukuran $70-230 \mathrm{~cm}$. Ikan hiu ini hidup di sekitar karang, dan sering juga di temukan di laut lepas dengan kedalaman 280 meter. Ikan hiu ini memiliki ciri ciri khusus seperti tepi sirip ekor bagian belakang berwarna hitam, ada guratan menonjol di antara sirip punggung yang tidak begitu jelas.

Empa' Hiu Sonteng (Carcharhinus albimarginatus) memiliki ujung sirip punggung, dada, perut, dan ekor berwarna putih. Terdapat gurat di antara sirip punggung, moncong agak panjang dan parabolik (tampak dari arah bawah). Bentuk gigi bagian atas segi tiga miring, bagian tepi mempunyai lekukan dan bergirigi, gigi bawah bergerigi halus dekat ujungnya, lebih ramping dan tegak daripada gigi bagian atasnya. Panjang tubuh dapat mencapai kirakira $300 \mathrm{~cm}$. Ukuran ketika lahir 73-81 cm.

Empa' Hiu Kejen (Carcharhinus limbatus) memiliki pangkal sirip punggung pertama di atas atau sedikit di belakang 
ujung celah sirip dada, gurat di antara sirip punggung tidak ada, sirip punggung, dada, dan bagian bawah sirip ekor polos pada hiu dewasa (berujung hitam pada hiu muda), moncong panjang, lancip (tampak dari arah bawah), gurat di sudut bibir atas pendek, tidak terlalu jelas terlihat, gigi atas dan bawah sama, hampir simetris; bentuk taring tegak dan ramping. Panjang tubuh dapat mencapai $255 \mathrm{~cm}$.

$$
\text { Empa' Hiu Merak Bulu }
$$

(Carcharhinus obscurus) memiliki pangkal sirip punggung pertama berhadapan dengan ujung belakang sirip dada, sisi bawah sirip punggung kedua panjang, terdapat gurat di antara sirip punggung, moncong pendek dan membundar (tampak dari arah bawah), tepi gigi gigi atas bergerigi, pendek, segi tiga melebar, ujungnya tegak hingga agak miring, gigi bawah kecil dan ramping, tegak lurus, pinggirannya bergerigi halus. Panjang tubuh dapat mencapai $360-400 \mathrm{~cm}$, ukuran ketika lahir antara 69-100 cm.

Empa' Hiu Macan (Galeocerdo cuvier) memiliki spirakel, kecil dan seperti celah, batang ekor pendek, bulat, dan terdapat guratan menonjol di sisinya, moncong sangat pendek dan bulat tumpul (tampak dari arah bawah), gurat di ujung bibir atas sangat panjang, hampir sama panjang dengan jarak ujung moncong ke mulut, gigi di kedua rahang bergerigi kasar, satu sisinya berlekuk dalam, sisi lainnya cembung. Panjang tubuh dapat mencapai $740 \mathrm{~cm}$. Ukuran ketika lahir antara 51-76 $\mathrm{cm}$.

Empa' Hiu Karet (Prionace glauca) memiliki dasar sirip punggung pertama lebih dekat ke dasar sirip perut daripada ke dasar sirip dada, sirip dada sangat panjang dan seperti sabit besar, batang ekor memiliki lunas (keel) yang lemah di kedua sisinya, bagian punggungnya berwarna biru nila, sedang bagian perutnya putih, dan moncong sangat panjang dan bulat menyempit (tampak dari arah bawah. Panjang tubuh dapat mencapai $383 \mathrm{~cm}$. Ukuran ketika lahir antara $35-44 \mathrm{~cm}$.

Empa' Pari Hias (Taeniura lymma) ukurannya hanya mencapai $35 \mathrm{~cm}$. Hidup di sekitar terumbu karang dengan kedalaman sampai 20 meter. Bermigrasi harian secara berkelompok, dari daerah karang ke daerah berpasir untuk mencari makan hewan-hewan yang bersembunyi di pasir seperti udang, molusca dan ikan - ikan kecil.

Empa' Mate Beleq (Priancanthus hamrur) dapat tumbuh hingga $45 \mathrm{~cm}$. Hidup di sekitar terumbu karang dengan kedalaman 250 meter. Hidup dalam kelompok kecil sampai besar, memakan udang, ikan kecil dan molusca.

Empa' Biji Nangka (Scolopsis sp) berukuran $20-40 \mathrm{~cm}$. Hidup dengan memakan berbagai jenis udang, molusca, dan larva ikan.

Empa' Tenggiri Tutul (Scombermorus guttatus) tumbuh hingga 2,5 meter dengan berat $83 \mathrm{~kg}$. Hidup di permukaan air sampai kedalaman 12 meter. Hidup soliter atau dalam kelompok kecil, hanya memakan ikan-ikan kecil dan molusca seperti cumi cumi dan sotong.

Empa' Tongkol (Euthynnus affinis) dapat tumbuh hingga mencapai 1 meter dengan berat maksimal $14 \mathrm{~kg}$, dan merupakan ikan pelagis yang hidup di pantai sampai laut lepas dengan kedalaman 200 meter. Ikan ini hidup berkelompok dengan memakan ikan-ikan kecil, udang, kepiting, molusca, dan plankton.

Empa' Kurisi Beaq (Nemipterus japonicas) hidup di dasar laut secara soliter atau dalam kelompok kecil. Ikan ini dapat tumbuh hingga 1 meter. Ikan ini memakan semua hewan kecil yang masuk dalam bukaan mulutnya.

Empa' Sembulak (Sardinella sp) banyak terdapat di perairan Selat Bali. Ikan ini banyak sebutannya seperti, jika badannya masih kecil disebut semenit atau sempenit, Jika beranjak dewasa dan panjang badannya 
Identifikasi Ikan Di Pelabuhan Perikanan Tanjung Luar...............(Slamet Mardiyanto Riyadi)

sekitar $12 \mathrm{~cm}$ dijuluki protolan. Ketika badannya mencapai $15 \mathrm{~cm}$ disebut lemuru. Tapi kalau ukurannya lebih besar lagi disebut lemuru kucing. Tapi ada juga di daerah lain di Bali seperti di Perairan Jimbaran, ikan lemuru ini disebut ikan kucing tanpa mempedulikan ukurannya.

Empa' Kakap Beaq (Lutjanus bitaeniatus) dapat tumbuh hingga ukuran 1 meter. Ikan ini hidup soliter atau dalam kelompok kecil, menghuni daerah karang yang lebih dalam ketika dewasa.

Empa' Semar (Secutor interruptus) dapat tumbuh sampai $15 \mathrm{~cm}$. Merupakan ikan dasar yang hidup di muara sungai dan pantai dangkal. Ikan ini biasa hidup di sekitaran pantai yang berlumpur/ berpasir untuk mencari makan.

Empa' Ucul /Senuk (Sphyraena jello) hidup di daerah payau, muara sungai, hutan bakau, pantai dan laut lepas dengan kedalaman 20 - 200 meter. Ikan yang masih muda hidup begerombol dalam jumah kecil, sedangkan yang sudah dewasa hidup soliter (menyendiri).

Empa' Kuwe (Caranx ignobilis) dapat tumbuh hingga mencapai $170 \mathrm{~cm}$. Ketika muda sangat menyukai perairan dengan kadar garam yang rendah, tetapi setelah besar dapat di temukan di berbagai zona laut.

\section{KESIMPULAN DAN SARAN}

\section{Kesimpulan}

Berdasarkan penelitian diperoleh sebanyak 34 jenis ikan hasil tangkapan nelayan di Pelabuhan Perikanan Tanjung Luar, Pulau Lombok, yaitu: Naso brevisrostris, Chanos chanos, Parastromateus niger, Thallasoma purpureum, Siganus canaliculatus, Plectorhinchus polytaenia, Diodon holocanthus, Upeneus vittatus, Caesio cuning, Dermogenys sp, Epinephelus areolatus, Rastrelliger sp, Pomadasys argenteus, Lepturacanthus savala, Decapterus macrosoma, Sillago sihama, Eusphyra blochii, Carcharhinus brevipinna, Carcharhinus albimarginatus, Carcharhinus limbatus, Carcharhinus obscurus, Galeocerdo cuvier, Prionace glauca, Taeniura lymma, Priancanthus hamrur, Scolopsis sp, Scombermorus guttatus, Euthynnus affinis, Nemipterus japonicas, Sardinella sp, Lutjanus bitaeniatus, Secutor interruptus, Sphyraena jello, dan Caranx ignobilis.

\section{Saran}

Perlu dilakukan penelitian lebih lanjut mengenai status konservasi dari berbagai jenis hasil tangkapan nelayan yang telah didaratkan di Pelabuhan Perikanan Tanjung Luar, Pulau Lombok.

\section{DAFTAR PUSTAKA}

Agus \& A. Laga. 2012. Komposisi Hasil Tangkapan Perikanan Tugu di Perairan Kota Tarakan. Jurnal Harpodon Borneo 5 (1): 83-90.

BAPPENAS. 2008. Database Pembangunan Kelautan dan Perikanan. Badan Perencanaan Pembangunan Nasional (BAPPENAS). Jakarta.

Barani, H.M. 2004. Pemikiran Percepatan Pembangunan Perikanan Tangkap Melalui Gerakan Nasional. Makalah Individu Pengantar ke Falsafah Sains. Sekolah Pasca Sarjana, Institut Pertanian Bogor. Bogor.

Dahuri, Rokhmin. 2001. Pengelolaan Sumberdaya Wilayah Pesisir dan Lautan

secara Terpadu. PT. Pradnya Paramita. Jakarta.

Direktorat Jenderal Perikanan. 1994. Pelabuhan Perikanan: Wahana Penyaluran 
Investasi Usaha. Direktorat Jenderal Perikanan. Jakarta.

Lubis, E. 2006. Pengantar Pelabuhan Perikanan. Bagian Pelabuhan Perikanan, Pemanfaatan Sumberdaya Perikanan, Fakultas Perikanan dan Ilmu Kelautan, Institut Pertanian Bogor. Bogor.

Lubis, E., I. Solihin, T. Nugroho \& R. Muninggar. 2010. Diktat Pelabuhan Perikanan.

Bagian Kepelabuhanan Perikanan dan Kebijakan Pengelolaan, Departemen Pemanfaatan Sumberdaya Perikanan, Fakultas Perikanan dan Ilmu Kelautan, Institut Pertanian Bogor. Bogor.

Nadia, L.A.R., Abdullah, A., Balubi \& A. Takwir. 2014. Rumpon Konservasi Berbasis Riset di Perairan Laut Kabupaten Konawe. Laporan Akhir Program Hi-Link tahun kedua. Universitas Halu Oleo. Kendari.

Nugroho, T. 2008. Bahan Kuliah Teknik Perencanaan Pembangunan dan
Pemanfaatan Pelabuhan Perikanan. Laboratorium Pelabuhan Perikanan, Departemen Pemanfaatan Sumberdaya Perikanan, Fakultas Perikanan dan Ilmu Kelautan, Institut Pertanian Bogor. Bogor.

Project AWARE Foundation. 2011. AWARE Shark Conservation. Project AWARE Foundation.

Sari, Y. Dewita, T. Kusumastanto \& L. Adrianto. 2008. Maximum Economic Yield Sumberdaya Perikanan Kerapu di Perairan Kepulauan Seribu, DKI Jakarta. Jurnal Bijak dan Riset Sosek Kelautan dan Perikanan 3 (1): 6971.

White, W.T., P.R. Last, Dharmadi, R. Faizah, U. Chodrijah, B.I. Prisantono, J.J. Pogonoski, M.Puckridge \& S.J.M. Blaber. 2013. Market Fishes of Indonesia. Australian Centre for International Agricultural Research. Canberra. 